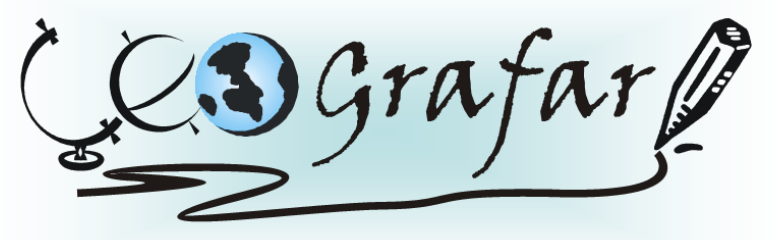

Revista Eletrônica do Programa de Pós-Graduação em Geografia - UFPR

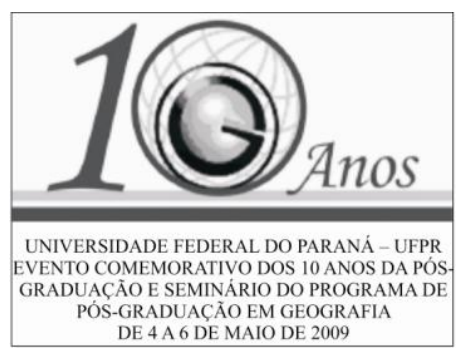

\title{
O ESPAÇO EM PEDAÇOS: PLANEJAMENTO URBANO E A DIVISÃO SOCIAL E TERRITORIAL NAS CIDADES, O CASO DO PLANO AGACHE EM CURITIBA
}

\author{
JULIO CESAR BOTEGA DO CARMO ${ }^{1}$ \\ OLGA LUCIA CASTREGHINI DE FREITAS FIRKOWSKI ${ }^{2}$
}

\section{PRODUÇÃO E TRANSFORMAÇÃO DO ESPAÇO URBANO E REGIONAL}

O presente trabalho, busca discutir a descrição e análise da aplicação de métodos e teorias urbanísticas a cidade de Curitiba, tentando demonstrar na prática como a ciência busca a compreensão plena da cidade, neste caso dando especial destaque a uma cidade brasileira e sua realidade de país emergente. Serão expostos os esquemas e trabalhos do plano Agache, de 1943, dando destaque ao que se convencionou definir como a imagem da cidade moderna, que impulsionada pela difusão do Capitalismo, sobretudo nas capitais, evidencia uma nova definição para suas funções, sejam elas de comando, produção, consumo ou sociais. Para definir os novos traçados da cidade, Agache usou como parâmetros a "eficiência" e a "salubridade". A eficiência se refletiria nas ruas largas e espaços comunitários generosos, abrindo caminho para os automóveis, para a luz e para o verde. A salubridade estava refletida na preocupação das autoridades com as grandes concentrações humanas na cidade, o aumento da ocupação irregular e o crescimento no número de "pobres", que atrapalhavam a "visibilidade", daí a idéia de se afastar a população carente dos centros comerciais e moradias burguesas, que se inspiraram nas intervenções de Haussmann em Paris. Assim, este processo levou a uma racionalização dos traçados da cidade, que antes tinha como base uma relação mais atrelada ao meio natural, o universo, não mais correspondendo às necessidades da população, daí a necessidade de se fazer um plano urbano que ainda hoje reflete na divisão espacial de Curitiba.

Palavras - chave: Planejamento urbano, Curitiba, Plano Agache

\footnotetext{
1 juliobotega@yahoo.com.br

2 Professora orientadora
} 